\title{
COLICINE K
}

\section{The Effect of Metabolites Upon Colicine Synthesis \\ By hIROShI MATSUSHITA,* M.D., MAURICE S. FOX, Ph.D. AND WALTHER F. GOEBEL, PH.D.}

(From The Rockefeller Institute)

(Received for publication, May 2, 1960)

The intestinal tract of man harbors a host of microorganisms some of which elaborate specific agents which are killers of other closely related bacteria,the colicines (1). Although some seventeen different types of colicine have been characterized, their nature still remains obscure (2). Several years ago this laboratory undertook to isolate one of these agents, colicine $\mathbf{K}$, to establish its chemical nature, and to learn something of its immunological properties as well. As a result of these studies it can now be said either that colicine $K$ is identical with the $\mathrm{O}$ antigen of the parent microorganism Escherichia coli $\mathrm{K}_{235}$, or that it is so intimately associated with the antigen that it cannot be separated from it by the purification procedures employed (3).

From the very beginning our studies revealed that the synthesis of colicine $\mathrm{K}$ was dependent upon environmental and nutritional factors. It was soon learned that when the microorganism was grown in synthetic media it produced only very small amounts of colicine. If such media were supplemented, however, with certain growth factors, the best of which is present in a dialysate of yeast extract, then the bacteria would synthesize sizable quantities of colicine $\mathrm{K}$ which was secreted into the medium near the end of the growth period.

In order to learn more of the relationship between metabolic conditions and colicine synthesis, a study has been undertaken of the growth of $E$. coli $\mathrm{K}_{235}$ in the chemostat, employing synthetic media supplemented with substances of well characterized composition. It will be seen that many factors govern the elaboration of colicine $\mathrm{K}$. Not only does the primary source of carbon determine in large measure the ability of the cell to synthesize colicine, but the $\mathrm{pH}$ of the medium, as well as the rate of growth of the microorganism, are likewise important factors.

\section{Materials and Methods}

Strains of Microorganisms. - The colicinogenic strains of $E$. coli used in this study were a colicine $\mathrm{K}$-producing microorganism known as $E$. coli $\mathrm{K}_{2 a 5} \mathrm{~L}_{+} \mathrm{O}$ (3), and a tryptophan-re-

* Present Address: Wakayama Medical College, Wakayama, Japan. 
quiring mutant, $E$. coli $\mathrm{K}_{236} \mathrm{Tr}^{-}-3$, obtained from the parent by a procedure described by Lederberg and Zinder (4) and by Davis (5). The reversion frequency of this mutant to tryptophan independence was very low. The tryptophan-requiring variant had the same ability to elaborate colicine $\mathrm{K}$ as did the parent. Throughout these studies $E$. coli $\mathrm{B}$ served as the sensitive host strain for colicine assays. All of the microorganisms were stored in 50 per cent horse serum-broth at $-18^{\circ} \mathrm{C}$.

Cullure Media.-The basic medium used in all of the experiments was the synthetic medium of Friedlein described in reference 6 . In certain instances, however, modifications were made and these are noted in the text. In those experiments in which the tryptophan-requiring mutant was studied, L-tryptophan was added to the basic medium in appropriate concentrations. When phosphorus served as the controlling growth factor, the mediurn was buffered by the addition of $0.05 \mathrm{M}$ tris.

Titration of Colicine Activity.-The colicine content of the whole culture and that of the cell-free supernate were determined by spotting serial dilutions of the solution to be tested on a lawn of the sensitive test organism, $E$. coli $\mathbf{B}(3)$. In one of the experiments it was necessary to employ a more precise method of assay, and hence the procedure of direct colony count was used (3). In the various tables and charts presented in this communication (except Fig. 5) the activity of the sample tested is expressed as units of colicine $K$ per milliliter. One unit of colicine is defined as that concentration of substance which gave complete inhibition of growth of $E$. coli B, and was equivalent to $1.0 \gamma$ per $\mathrm{ml}$. In order to kill the bacteria in the sample to be assayed, the solution was heated at $56^{\circ} \mathrm{C}$. for 30 minutes. This procedure was adapted, rather than killing with chloroform, because it was observed that some loss in activity occurred when air was bubbled through a solution of colicine $K$ containing chloroform.

Colony Counts and Turbidity Measurements.-The turbidities of the various cultures were measured by means of a photoelectric turbidometer (7). Dilutions were made either with saline or with the medium in which the bacteria were grown, such that the turbidity readings were in all instances of approximately the same value. The bacterial cells were counted by the usual agar layer method.

Chemostat Apparatus. -The elaboration of colicine $\mathrm{K}$ at various growth rates was studied in the continuous culture apparatus, or chemostat, described by Novick and Szilard (8). Nutrient medium was supplied to the bacteria in the growth tube of the apparatus at a preselected rate of $w \mathrm{ml}$./hour, and was controlled by a solenoid valve which was periodically tripped by a clock mechanism. The volume $V$ of bacterial suspension in the growth tube was maintained at a constant level by an overflow syphon, and was stirred by bubbling sterile air through the culture tube. In order to reach equilibrium in the stationary state, in which the growth rate of the bacteria was equal to the dilution rate $\left(\alpha /\right.$ hour $\left.=\frac{w}{V}\right)$, growth of the microorganism was maintained at a given flow rate after the population of bacteria reached a maximum, for at least 3 times the period of the generation time ( $\tau$ hours). The latter is defined as the reciprocal of the dilution rate.

\section{EXPERIMENTAL}

The Effect of Nutritional Factors on the Production of Colicine $K$ by $E$. coli $K_{235}$.- In the experiments in which the chemostat is employed the fresh nutrient which enters the growth tube must contain all of the factors needed for the growth of the bacteria in excess except one. The latter is termed the controlling growth factor. In the study about to be described, phosphorus was used as the controlling growth factor for the wild type of $E$. coli $\mathrm{K}_{236}$, and both 
phosphorus and tryptophan for the tryptophan-requiring mutant, E. coli $\mathrm{K}_{235}$ $\mathrm{Tr}^{-}$-3. In all of the experiments the concentration of the controlling growth factor was such that the bacterial density never exceeded $10^{9}$ per ml.

From previous studies conducted in this laboratory it was reasonably well established that the production of colicine $\mathbf{K}$ during the later stages of bacterial growth parallels the multiplication of the bacteria when they are grown in an enriched medium (3). For the purposes of this study, however, it was desirable to employ a medium of less complexity. Attempts were therefore made to ascertain the simplest possible medium which would permit the production of large amounts of colicine $\mathrm{K}$. The results of one such preliminary experiment are

TABLE I

Effect of Acetate and Citrate upon Colicine $K$ Production by E. coli $K_{235} T^{-}-3$

\begin{tabular}{|c|c|c|c|c|c|c|}
\hline Carbon source & Buffer & $\begin{array}{l}0.02 \text { y am- } \\
\text { monium salt }\end{array}$ & $\begin{array}{l}\text { Turbidity } \\
\text { of culture }\end{array}$ & $\begin{array}{l}\text { Colonies in } \\
\text { culture }\end{array}$ & $\begin{array}{l}\text { Colicine } K \text { in } \\
\text { supernate }\end{array}$ & $\begin{array}{l}\text { Final pH } \\
\text { of culture }\end{array}$ \\
\hline per cent & & Chloride & 2700 & $\begin{array}{c}\text { per ml. } \\
6.8 \times 10^{9}\end{array}$ & $\begin{array}{c}\text { units per ml. } \\
<2\end{array}$ & 6.79 \\
\hline 0.2 glucose & $0.05 \mathrm{M}$ maleate & $\begin{array}{l}\text { Acetate } \\
\text { Citrate }\end{array}$ & $\begin{array}{l}2520 \\
2640\end{array}$ & $\begin{array}{l}5.6 \times 10^{\circ} \\
5.9 \times 10^{9}\end{array}$ & $\begin{array}{l}<2 \\
<2\end{array}$ & $\begin{array}{l}7.92 \\
6.76\end{array}$ \\
\hline & & Chloride & 3000 & $6.1 \times 10^{9}$ & 8 & 5.92 \\
\hline 0.5 glycerol & 0.05 M maleate & $\begin{array}{l}\text { Acetate } \\
\text { Citrate }\end{array}$ & $\begin{array}{l}3280 \\
2700\end{array}$ & $\begin{array}{l}6.6 \times 10^{9} \\
5.6 \times 10^{9}\end{array}$ & $\begin{array}{r}8 \\
64\end{array}$ & $\begin{array}{l}5.90 \\
6.17\end{array}$ \\
\hline 0.9 lactate & $0.05 \mathrm{M}$ tris & $\begin{array}{l}\text { Chloride } \\
\text { Acetate } \\
\text { Citrate }\end{array}$ & $\begin{array}{l}4920 \\
5670 \\
4680\end{array}$ & $\begin{array}{l}6.5 \times 10^{9} \\
6.2 \times 10^{9} \\
4.8 \times 10^{9}\end{array}$ & $\begin{array}{r}1024 \\
32 \\
32\end{array}$ & $\begin{array}{l}8.33 \\
8.13 \\
8.29\end{array}$ \\
\hline
\end{tabular}

given in Table $\mathrm{I}$ in which the effects of acetate and citrate upon colicine synthesis are summarized.

In this experiment glucose, glycerol, or lactate served as the primary carbon source. The acetate and citrate were employed as their ammonium salts at a concentration of $0.02 \mathrm{M}$. A control tube was incorporated in each experiment in which ammonium chloride was substituted for the acetate or citrate. The media which had been adjusted to $\mathrm{pH} 6.8$ contained, in addition to the substances noted in the table, $0.2 \mathrm{gm}$. of $\mathrm{MgSO}_{4}, 0.2$ per cent technical casamino acids, $100 \mathrm{mg}$. of phosphorus, and $100 \mathrm{mg}$. of L-tryptophan per liter. In all experiments the bacteria were grown with aeration for 17 hours.

In these experiments Friedlein's medium, to which 0.2 per cent casamino acids had been added, was again used as the basal culture medium. In one experiment, 1.5 per cent glucose served as the carbon source, in the other, 0.9 per cent lactic acid was employed. Both media were placed in 2 liter wide mouth Erlenmeyer flasks, adjusted to $\mathrm{pH} 7.0$, and after sterilization, each was seeded with $1 \times 10^{10}$ cells of a strain of $E$. coli $\mathrm{K}_{235} \mathrm{~L}_{+} \mathrm{O}$ which had been adapted to growth in the minimal medium.

The flasks were now fitted with the assemblies for $\mathrm{pH}$ control and the cultures were maintained at $37^{\circ} \mathrm{C}$. without aeration for 6 hours. At this juncture the growth in the flask had 
TABLE II

Production of Colicine $K$ by E. coli $K_{235} L_{+} O$ in Glucose-Minimal Medium Maintained at $p H 7.0$

\begin{tabular}{c|c|c|c|c|c}
\hline \multirow{2}{*}{ Time } & \multirow{2}{*}{$\begin{array}{c}\text { Turbidity of } \\
\text { culture }\end{array}$} & Colonies & \multicolumn{3}{|c|}{ Units of colicine K per 108 cells } \\
\cline { 3 - 6 } & & Whale culture & Supernate & $\begin{array}{c}\text { Bacterial } \\
\text { cells* }\end{array}$ \\
\hline chrs. & & per ml. & & & \\
0 & 230 & $3.4 \times 10^{8}$ & 6 & $<0.2$ & 6 \\
1 & 690 & $1.0 \times 10^{9}$ & 2 & 0.2 & 2 \\
2 & 1140 & $1.7 \times 10^{9}$ & 4.7 & 1.0 & 4 \\
3 & 1770 & $3.1 \times 10^{9}$ & 2.6 & 0.65 & 2 \\
4.2 & 2130 & $4.4 \times 10^{9}$ & 1.8 & 0.9 & 1 \\
5 & 2400 & $4.7 \times 10^{9}$ & 1.7 & 1.7 & 0 \\
6 & 2760 & $4.9 \times 10^{9}$ & 3.3 & 1.6 & 2 \\
7 & 2880 & $5.1 \times 10^{9}$ & 1.6 & 1.6 & 0 \\
8.2 & 3200 & $6.3 \times 10^{9}$ & 1.3 & 1.3 & 0 \\
18 & 4500 & $8.6 \times 10^{9}$ & 0.9 & 0.1 & 0.8 \\
\hline
\end{tabular}

* The values in this column and those in Tables II, III, and V are obtained by subtracting the units of colicine $K$ in the supernate from those in the whole culture.

TABLE III

Production of Colicine $K$ by $E$. coli $K_{235} L_{+} O$ in Lactate-Minimal Medium Maintained at $p H 7.0$

\begin{tabular}{c|c|c|c|c|c}
\hline Time & $\begin{array}{c}\text { Turbidity of } \\
\text { culture }\end{array}$ & Colonies & \multicolumn{2}{|c|}{ Units of colicine K per 108 cells } \\
\cline { 3 - 5 } & & Whole culture & Supernate & Bacterial cells \\
\hline hrs. & & per ml. & & & \\
3 & 230 & $1.6 \times 10^{8}$ & 6.2 & $<0.1$ & 6 \\
4 & 540 & $4.2 \times 10^{8}$ & 4.8 & $<0.1$ & 5 \\
5 & 920 & $1.5 \times 10^{9}$ & 2.7 & 0.1 & 2 \\
6 & 1880 & $2.6 \times 10^{9}$ & 3.1 & 1.2 & 2 \\
7 & 2680 & $4.2 \times 10^{9}$ & -5 & 1.5 & -1 \\
8 & 3400 & $4.4 \times 10^{9}$ & 7.3 & 2.9 & 4 \\
9 & 4200 & $7.8 \times 10^{9}$ & 8.2 & 3.0 & 5 \\
10 & 3720 & $8.0 \times 10^{9}$ & 8.0 & 3.2 & 5 \\
17 & 3800 & $7.0 \times 10^{9}$ & 18.0 & 18.0 & $2.3^{*}$ \\
\hline
\end{tabular}

* Direct determinations on centrifuged, washed cells.

reached approximately $1 \times 10^{8}$ cells $/ \mathrm{ml}$. Aeration was now begun ( 3 liters $/$ minute). The $\mathrm{pH}$ of the media was maintained by the automatic addition of 0.5 molar $\mathrm{Na}_{2} \mathrm{CO}_{3}$ solution in the case of the glucose medium, and of $0.5 \mathrm{~N} \mathrm{HCl}$ in the case of the lactate medium. Samples were removed for colicine assay at hourly intervals. In this manner the increase in bacterial population, as well as the production of colicine $K$ by the whole culture and its elaboration 
into the culture medium, was carefully followed. The results of these tests are presented in Tables II and III.

From the data presented in Table $I$ it will be noted that in lactate-minimal medium both citrate and acetate have a strong inhibitory action on the production of colicine $\mathrm{K}$. On the other hand, in the medium in which glycerol served as the carbon source, citrate enhanced the production of the colicine, but acetate did not. In the glucose-containing medium, however, neither substance stimulated colicine $K$ production. The reasons for the poor production of colicine in the media containing glucose or glycerol will be discussed later.

The Production of Colicine $K$ in Cultures Maintained at $p H$ 7.0.-Because of the fact that $E$. coli $\mathrm{K}_{235}$ produces but little colicine when grown in the basal medium containing glucose, and elaborates larger amounts when lactate serves as the primary carbon source, it seemed desirable to study the growth of the microorganism in the two media under conditions in which the $\mathrm{pH}$ of the culture was maintained at a constant value. For this purpose an apparatus described in a previous study was employed (3).

It will be observed that initially the bacteria grew more slowly in the lactate medium than in the medium containing glucose, and that some 10 hours after the beginning of aeration the bacterial densities had reached approximately the same high level in both cultures. The amounts of colicine $\mathrm{K}$, calculated on the basis of units of colicine per $10^{8}$ cells, were quite different, however.

In the glucose-containing medium colicine was liberated into the medium during the early part of the experiment by the rapidly multiplying microorganisms, but the concentration of colicine both in the supernate and particularly in the whole culture, did not increase in proportion to the number of bacteria as they grew to saturation. From Table II it can be seen that the colicine $\mathrm{K}$ content of the whole culture, expressed as units per $10^{8}$ cells, decreased gradually, although that of the cell-free supernate increased during the 5 to 6 hours after aeration was initiated. It was also observed that a decrease of colicine in the supernate and of total colicine occurred at the end of the experiment, when the bacterial density had almost reached a maximum. This observation is in accord with those made previously in this laboratory (3).

The events, however, are quite different when the bacillus is grown in lactate medium, for here the liberation of colicine is slower during the early stages of growth. Furthermore, the colicine content of both the supernate and of the whole culture increases, and there is no diminution at the end of the growth curve, where the concentrations of colicine reach a maximum of 18 units $/ 10^{8}$ bacteria (Table III). These results are in agreement with the preliminary experiments recorded in Table I. One of the interesting things revealed in this table is the fact that the amount of intracellular colicine $\mathrm{K}$ per $10^{8}$ cells was maintained at a constant level throughout bacterial growth. This is quite 
different from the result presented in Table II, which shows that a rapid decrease in the colicine of both the whole culture and of the supernate takes place after the bacteria reach saturation in glucose medium. When the same experiments were repeated with the tryptophan-requiring mutant $E$. coli $\mathrm{K}_{235}$ $\operatorname{Tr}^{-}-3$, the results were essentially the same.

In sum, it can be concluded either that an inactivation of colicine $\mathrm{K}$ occurs when the colicinogenic bacillus is grown in the medium containing glucose, or

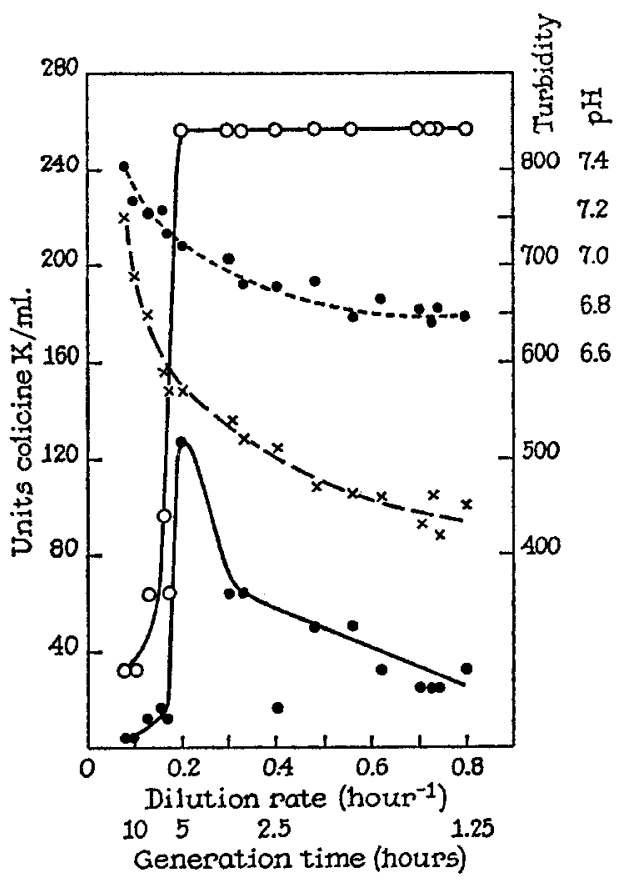

Fig. 1. Elaboration of colicine $\mathrm{K}$ by $E$. coli $\mathrm{K}_{235} \mathrm{~L}_{+} \mathrm{O}$ grown in phosphorus-limiting lactate medium. $\mathrm{O}-\mathrm{O}$, colicine content of whole culture; $\bullet-\bullet$, colicine content of supernate; X-... $\times$, turbidity; $-\cdots, \mathrm{pH}$ of culture medium.

that glucose itself suppresses the synthesis of colicine. When the microorganism is grown in lactate medium this is not the case, however. In fact, it appears that lactate actually stimulates colicine synthesis.

The Production of Colicine $K$ during Growth of E. coli $K_{235}$ in the Stationary State.-A study of the growth of the colicinogenic bacillus in the Szilard-Novick chemostat was next undertaken in order to obtain additional information regarding the synthesis and elaboration of colicine $\mathrm{K}$. This instrument permits one to maintain exponentially growing bacteria under constant environmental conditions ("stationary state") at various preselected generation times. The latter may be varied at will between generation times approaching the maximum 
for the particular medium employed, and very long generation times, approaching conditions under which the bacteria stop growing.

The chemostat was maintained at $37^{\circ} \mathrm{C}$. in an incubator room. The growth tube containing the medium was seeded with the appropriate organism and samples of the culture

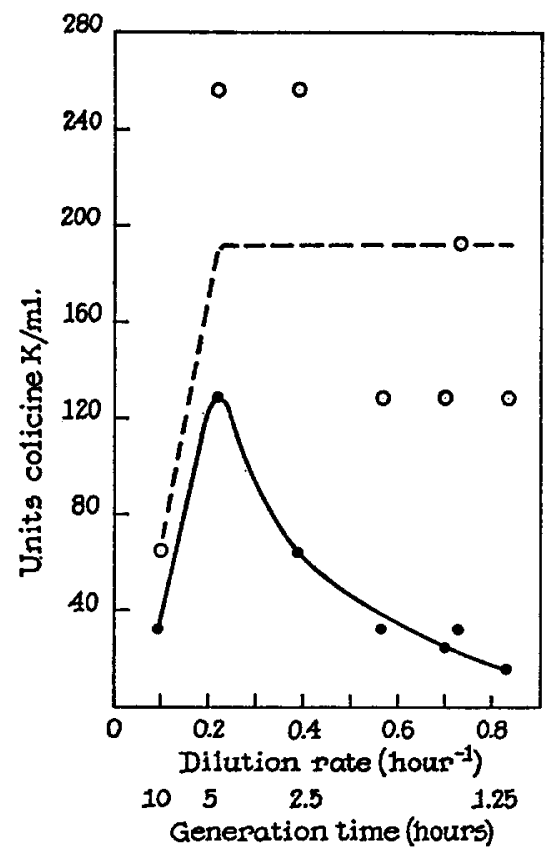

FIG. 2. Elaboration of colicine $\mathrm{K}$ by $E$. coli $\mathrm{K}_{235} \mathrm{Tr}^{-}-3$ grown in tryptophan-limiting lactate medium. $\mathrm{O}-\cdots \mathrm{O}$, colicine content of whole culture; $-\bullet$, colicine content of supernate.

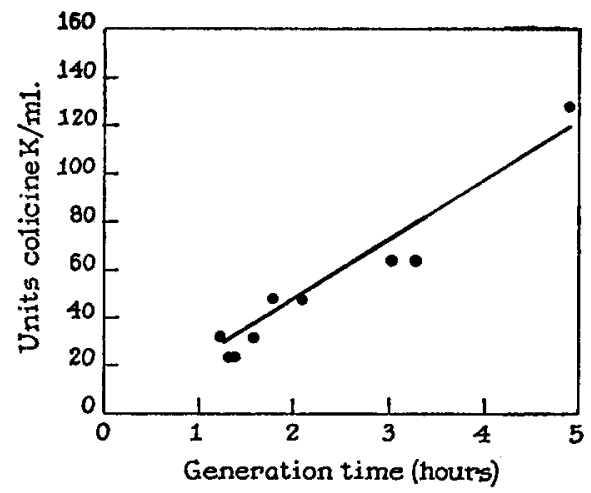

Fig. 3. Elaboration of colicine $\mathrm{K}$ in supernate by $E$. coli $\mathrm{K}_{235} \mathrm{~L}_{+} \mathrm{O}$ at varying generation times. 
were removed after the bacterial population had reached a stationary state for a given generation time. The $\mathrm{pH}$ of the culture and its turbidity were then measured and cell counts were made. In addition, the amount of colicine $\mathrm{K}$ in the supernate and in the whole culture were determined. In all of the experiments the stock media were supplemented with 0.2 per cent casamino acids containing 0.40 per cent phosphorus, but no tryptophan. In the experiments

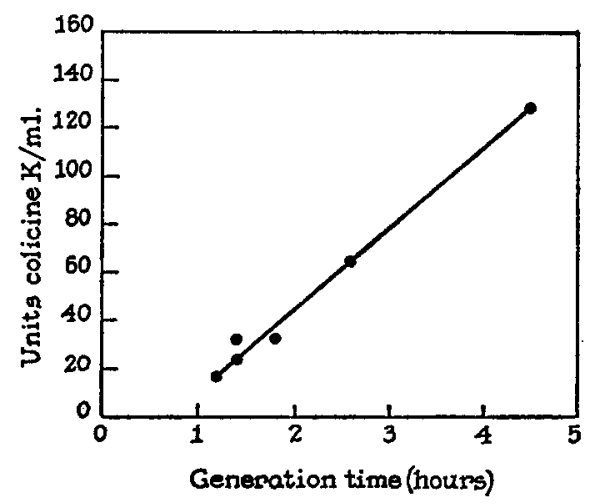

FIG. 4. Elaboration of colicine $\mathrm{K}$ in supernate by $E$. coli $\mathrm{K}_{235} \mathrm{Tr}^{-}-3$ at varying generation times.

TABLE IV

Production of Colicine $K$ by $E$. coli $K_{235} L_{+} O$ in Lactate-Minimal Medium at Different $p H$ Values

\begin{tabular}{c|c|c|c}
\hline \multicolumn{2}{c|}{$\mathrm{pH}$} & Turbidity of culture & $\begin{array}{c}\text { Colicine K in whole } \\
\text { culture }\end{array}$ \\
\hline Initial & Final & & \\
\hline & & 660 & 64 \\
6.35 & 6.53 & 690 & 128 \\
6.60 & 6.73 & 640 & 256 \\
6.80 & 6.88 & 720 & 128 \\
7.00 & 7.11 & 740 & 64 \\
7.26 & 7.22 & 660 & 32 \\
7.50 & 7.39 & & unis per ml. \\
\hline
\end{tabular}

where lactate served as the primary source of carbon, lactic acid was added to the medium to a concentration of 0.9 per cent. Ammonium chloride $(2.0 \mathrm{gm}$./liter) was likewise added and the medium, adjusted to $\mathrm{pH} 6.8$, was buffered with $0.05 \mathrm{M}$ tris.

Figs. 1 and 2 represent the results of experiments in which E. coli $\mathbf{K}_{235}$ was grown for various generation times in the media described and in which phosphorus and tryptophan were employed as the controlling growth factors. In general, the bacterial density which is established in the growth tube in the stationary state is proportional to the concentration of the controlling growth 
factor in the stock medium in the reservoir. In the experiments in which phosphorus $(15 \mathrm{mg}$./liter) was the controlling growth factor, densities of 5 to $10 \times$ $10^{8} \mathrm{bacteria} / \mathrm{ml}$. were reached (Figs. 1 and 3). In those experiments in which tryptophan served as the controlling growth factor, the variant $E$. coli $\mathrm{K}_{235}$ $\operatorname{Tr}^{-}-3$ grew to densities of 6.0 to $8.0 \times 10^{8} \mathrm{bacteria} / \mathrm{ml}$. when the I-tryptophan concentration of the culture medium was $3 \mathrm{mg}$./liter (Figs. 2 and 4). With increasing generation times, the bacterial densities rose as one can see from Fig. 1.

In those experiments where phosphorus served as the controlling growth factor, it is quite possible that its concentration in the growth tube during the stationary state constitutes a significant fraction of the concentration in the reservoir. If this is indeed the case, this fraction of unused phosphorus would necessarily diminish as the generation time increased, and thus would permit an increase in bacterial density. This consideration seems to be less relevant in the experiments in which tryptophan served as the controlling growth factor. Although cells grown at increasing generation times show some changes in their microscopic appearance, the ratio of the optical density of the culture at 450 $\mathrm{m} \mu$, or its turbidity, to cell count does not change.

From Fig. 1 it may be seen that the total amount of colicine $K$ present in the culture remains constant and at a high level between generation times of 1.2 to 5 hours. In the experiments in which tryptophan served as the controlling growth factor (Fig. 2), the results are less satisfactory and for the present cannot be fully evaluated. In regard to the experiment described in Fig. 1 it may be said, however, that the rate of production of colicine $\mathrm{K}$, like over-all growth and protein synthesis, is controlled solely by the concentration of the growth factor in the growth tube. From the data presented in Figs. 1 and 2 it is possible to relate the quantity of colicine found in the supernate of the growing bacteria to their generation times.

Figs. 3 and 4 show the amount of supernate colicine plotted as a function of generation time. It can be clearly seen that the amount of the colicine $K$ in the supernate is proportional to the generation time between generation times of 1.2 and 5 hours. Within these limits, colicine $\mathrm{K}$ is secreted at a constant rate of approximately 20 to 25 units/hour for bacterial densities of about $5 \times$ $10 \% \mathrm{ml}$. and is independent of the generation time.

At very slow rates of growth the total amount of colicine $K$ is no longer constant; there is a great reduction of both total and supernate colicine $\mathrm{K}$, caused perhaps by the reduction in concentration of some metabolite necessary for the production of colicine. One such possibility is the reduction in concentration of lactic acid in the acid form, as a consequence of the $\mathrm{pH}$ shift to more alkaline values. The $\mathrm{pH}$ in the growth tube became increasingly alkaline as the dilution rates decreased below 0.2 hour ${ }^{-1}$.

In order to examine the possibility of a suppression of colicine $\mathrm{K}$ synthesis in alkaline media, the following experiment was carried out. 
$10 \mathrm{ml}$. of the same medium as that used in the experiment described in Fig. 1, but containing excess phosphorus, was placed in a series of tubes and the $\mathrm{pH}$ in each was adjusted to the values indicated in Table IV. The tubes were now seeded with a growing culture of $E$. coli $\mathrm{K}_{235} \mathrm{~L}_{+} \mathrm{O}$ which had been adapted to growth on minimal medium. At the beginning of the

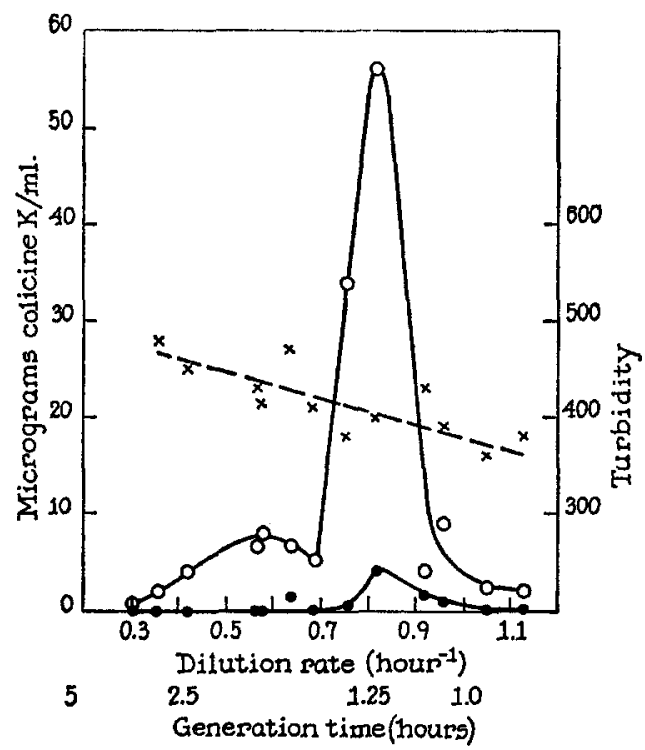

Fig. 5. Elaboration of colicine $\mathrm{K}$ by $E$. coli $\mathrm{K}_{235} \mathrm{Tr}^{-}-3$ in glucose medium under aerobic condition. $\mathrm{O}-\mathrm{O}$, colicine content of whole culture; $-\longrightarrow$, colicine content of supernate; $\times-\cdots-\triangle$, turbidity.

\section{TABLE V}

Production of Colicine $K$ by E. coli $K_{235} L_{+} O$ in an Anaerobic Glucose-Minimal Medium Maintained at $p H 7.0$

\begin{tabular}{c|c|c|c|c|c}
\hline \multirow{2}{*}{ Time } & \multirow{2}{*}{ Turbidity } & Colonies & \multicolumn{3}{|c}{ Onits of colicine K per 108 cells } \\
\cline { 3 - 5 } & & & Whole culture & Supernate & Bacterial cells \\
\hline hrs. & & per ml. & & & \\
18.5 & 1920 & $2.7 \times 10^{9}$ & 4.7 & 9.5 & 5 \\
22 & 1640 & $2.1 \times 10^{9}$ & 6.1 & 12.2 & 6 \\
\hline
\end{tabular}

experiment the turbidity of each sample was 20 . The bacteria were grown for 4.5 hours at $37^{\circ} \mathrm{C}$. with aeration until they had reached a concentration of approximately $1 \times 10^{\circ}$ bacteria/ ml., well below saturation.

From Table IV it can be clearly seen that the highest production of colicine $\mathrm{K}$ occurred in the medium which had been adjusted to $\mathrm{pH}$ 6.8-6.9. Its production fell off sharply as the $\mathrm{pH}$ of the medium was shifted either to the acid or 
alkaline side, although the bacterial growth in each sample reached essentially the same level. From this experiment it may be concluded that in the chemostat the diminution in production of colicine $\mathrm{K}$ in the medium containing lactate can be attributed to the change of $\mathrm{pH}$ which occurs at the very slow growth rates.

Further experiments were carried out in the chemostat in order to observe the production of colicine when glucose served as the primary carbon source.

In this experiment glucose was used at a concentration of 0.25 per cent and the medium at $\mathrm{pH} 7.0$ was buffered with 0.07 molar phosphate and the concentration of $L$-tryptophan, the growth-controlling factor, was $2.8 \mathrm{mg}$./liter. Because the amounts of colicine produced were so small, it was necessary to determine their concentrations by the more sensitive colony count procedure (3). In these experiments the $\mathrm{pH}$ in each sample remained almost constant, i.e. it did not change from the initial value, within the limits of measurement. The turbidity increased as the dilution rate decreased. On the other hand, the viable count also changed from $5.0 \times 10^{8} / \mathrm{ml}$. to $9.0 \times 10^{8} / \mathrm{ml}$.

The results of this experiment, presented in Fig. 5, are quite different from those shown in Figs. 1 and 2, for here it is seen that colicine production is very low at fast growth rates, and that it rises to a sharp maximum as the rate diminishes to 0.8 hours $^{-1}$. At still longer generation times the colicine production falls sharply. Even at its maximum, at a generation time of 1.2 hours, the yield of colicine in the whole culture was approximately a quarter of that obtained in lactate medium. A similar experiment could not be attempted, employing phosphorus as a growth controlling factor, since no satisfactory buffer was available.

From this experiment it is apparent that when the colicinogenic microorganism is grown in a lactate medium, it produces much more colicine than when grown in a medium containing glucose. It is possible that cells which are grown on glucose actually produce their colicine as a consequence of the accumulation of lactate in the medium. In order to examine this possibility, experiments were carried out in which the colicinogenic bacillus was grown under anaerobic conditions in the medium to which glucose was added.

\section{The Production of Colicine $K$ Under Anaerobic Conditions.-}

As in previous experiments (Table II) the bacteria were grown in 1 liter of minimal medium supplemented with 0.2 per cent casamino acids and 1.5 per cent glucose. The medium was contained in a 2 liter wide mouth Erlenmeyer flask through which nitrogen gas containing 5 per cent $\mathrm{CO}_{2}$ was bubbled at a rate of 1 liter/minute. The $\mathrm{pH}$ of the medium was maintained constant at $\mathrm{pH}$ 7.0. The inoculum of $E$. coli $\mathrm{K}_{235} \mathrm{~L}_{+} \mathrm{O}$ was prepared by growing the bacillus in a small sample of medium which was kept anaerobic by bubbling nitrogen gas through the culture tube.

The results of the anaerobic experiment are presented in Table V. If one compares the data presented here with those in Table II, it is apparent that the amounts of colicine $\mathrm{K}$ both in the supernate and in the whole culture is rela- 
tively high despite the rather low yield of bacteria. The amount of intracellular colicine $\mathrm{K}$ was calculated and was found to be about equal to that obtained in lactate medium (Table III).

A chemostat experiment was also carried out under anaerobic conditions, employing the same medium as that used in the experiment described in Fig. 5. In this experiment the controlling growth factor L-tryptophan was supplied at a concentration of $3.0 \mathrm{mg}$./liter. Here too anerobiosis was achieved by using the nitrogen-carbon dioxide mixture, both to maintain pressure in the reservoir, and to mix the bacteria in the growth tube. Throughout the experiment the $\mathrm{pH}$ of the various samples in the growth tube remained constant at about

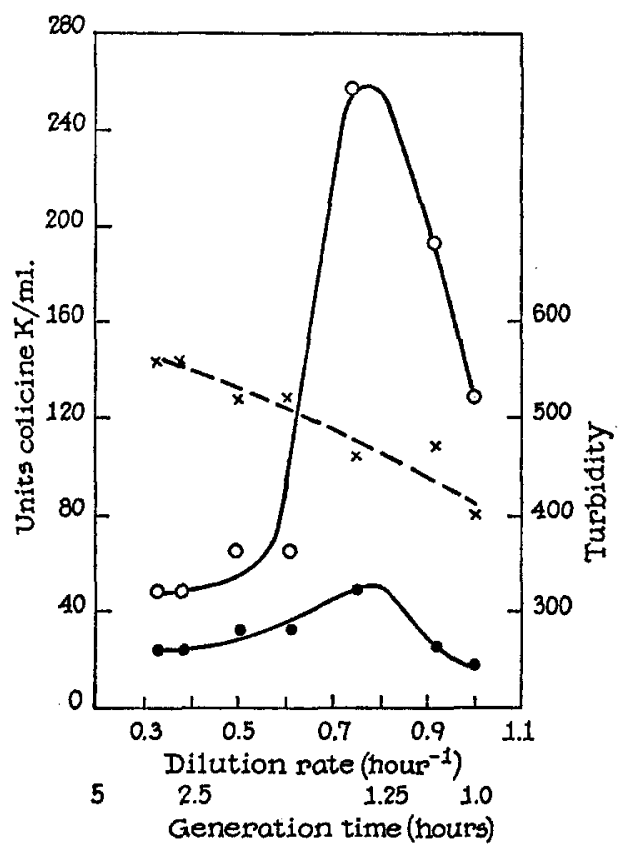

Fig. 6. Elaboration of colicine $\mathrm{K}$ by $E$. coli $\mathrm{K}_{235} \mathrm{Tr}^{-}-3$ in glucose medium under anaerobic conditions. $\mathrm{O}-\mathrm{O}$, colicine content of whole culture; $-\bullet$, colicine content of supernate; $X-\cdots-X$, turbidity.

6.6, a value somewhat more acid than that in the experiments described in Fig. 5. The viable cell counts varied from $5.0 \times 10^{8} / \mathrm{ml}$. to $9.0 \times 10^{8} / \mathrm{ml}$. as the dilution rate decreased.

The results of this experiment, which are presented graphically in Fig. 6, are similar to those of the previous experiment. Both the curve of total colicine and that of the supernate colicine show a maximum peak at a generation time of approximately 1.2 hours. The most striking observation, however, is that under anaerobic conditions there is at all generation times a markedly higher yield of colicine than when the microorganism is grown aerobically. The fact that the production of colicine is enhanced by anaerobic conditions is quite consistent with the hypothesis that lactic acid must be implicated in the production of this antibacterial agent. 
DISCUSSION

Our work of the past several years has revealed that the production of colicine $\mathrm{K}$ by $E$. coli $\mathrm{K}_{235}$ is greatly influenced by certain environmental and physiological factors. In the study which has been presented here, several of these have been examined in detail,- the nature of the primary carbon source, the metabolism of glucose by the colicinogenic bacillus under aerobic and anaerobic conditions, the $\mathrm{pH}$ of the medium, and finally the generation time of the microorganism itself. It has been found that when the colicinogenic bacillus is grown in the presence of lactic acid, it produces far more colicine $K$ than when it is cultivated in the same medium in which glucose is substituted for lactic acid. It would seem from this that lactic acid is implicated in colicine $\mathrm{K}$ synthesis, an hypothesis which finds support in the observation that colicine production is far greater under anaerobic, than under aerobic conditions when glucose serves as the primary carbon source. In the chemostat, under anaerobic conditions, the fermentative metabolism of the microorganism permits the accumulation of lactic acid, and the maximum amount of colicine $\mathrm{K}$ which is elaborated reaches a level in excess of 40 units per $10^{8}$ cells (Fig. 6). This amount is comparable to, or perhaps even greater than that produced when the colicinogenic bacillus is grown in a medium where lactate serves as the carbon source (Fig. 1).

Our study has also revealed that when the bacteria are grown at various preselected generation times in a medium containing glucose, colicine production increases very rapidly as the generation time is increased from 0.8 to 1.2 hours (Figs. 5 and 6$)$. At the shortest generation time ( 0.8 hour) the amount of colicine produced is comparable to that elaborated by the bacteria when they multiply at their maximum rate at constant $\mathrm{pH}$ (Table III).

In a medium in which lactate serves as the primary carbon source the total quantity of colicine synthesized remains constant between generation times of 1.2 and 5 hours (Fig. 1). However, the amount of colicine which is secreted into the medium increases linearly with the generation time (Figs. 3 and 4). Thus, over a range of generation times lying between 1.2 and 5 hours, colicine is synthesized at a rate proportional to the growth rate of the bacteria and is secreted into the medium at a constant rate independent of the growth rate. The total amount of colicine synthesized under these conditions does not differ greatly from that elaborated by the bacteria during the latter part of their growth cycle when they are grown under conditions of constant $\mathrm{pH}$ (Table III).

It was observed, furthermore, that a great reduction in colicine synthesis takes place at very slow growth rates (generation times longer than 5 hours). This phenomenon may be accounted for by the fact that at long generation times a shift in $\mathrm{pH}$ occurs toward the alkaline range.

In the chemostat experiments, in which glucose served as the carbon source, colicine production under both aerobic and anaerobic conditions shows a sharp 
maximum at a generation time of 1.2 hours. Here the amount of colicine $\mathrm{K}$ reaches a value of 10 units per $10^{8}$ bacteria in the aerobic chemostat, and in the anaerobic experiment the peak is 40 to 50 units per $10^{8}$ bacteria. At generation times longer than 1.2 hours, however, the elaboration of colicine drops sharply. Although the reason for this is not clear, the phenomenon might be similar to that which occurs at the termination of growth of the colicinogenic bacillus in media maintained at constant $\mathrm{pH}$ (Table II). Perhaps the cells themselves destroy the colicine, yet the few experiments which we have performed have failed to substantiate this hypothesis. In conclusion it can be stated that the elaboration of colicine $\mathrm{K}$ by $E$. coli $\mathrm{K}_{235}$ is influenced by certain nutritional factors and that the experiments reported in this communication strongly implicate lactic acid.

\section{SUMMARY}

The synthesis of colicine $\mathrm{K}$ by the colicinogenic bacillus $E . \operatorname{coli} \mathrm{K}_{235}$ has been studied in the chemostat.

It has been found that colicine production is influenced by the $\mathrm{pH}$ of the medium, by the nature of the primary carbon source, and by the generation time of the microorganism.

\section{BIBLIOGRAPHY}

1. (a) Gratia, A., Sur un remarquable exemple d'antagonisme entre deux souches de colibacille, Compt. rend. Soc. biol., 1925, 93, 1040. (b) Gratia, A., Antagonisme microbien et "bactériophageie," Ann. Inst. Pasteur, 1932, 48, 413. (c) Fredericq, P., Colicine et bactériophages, Ann. Inst. Pasteur, 1953, 84, 294.

2. Adams, M. H., Bacteriophages, New York, Interscience Publishers, Inc., 1959, 381.

3. (a) Goebel, W. F., Barry, G. T., and Shedlovsky, T., Colicine K. I. The production of colicine $\mathrm{K}$ in media maintained at constant $\mathrm{pH}, J$. Exp. Med., 1956, 103, 135. (b) Goebel, W. F., and Barry, G. T., Colicine K. II. The preparation and properties of a substance having colicine $\mathrm{K}$ activity, $J$. Exp. Med., 1958, 107, 185. (c) Amano, T., Goebel, W. F., and Smidth, E. M., Colicine K. III. The immunological properties of a substance having colicine $\mathrm{K}$ activity, J. Exp. Med., 1958, 108, 731.

4. Lederberg, J., and Zinder, N., Concentration of biochemical mutants of bacteria with penicillin, J. Am. Chem. Soc., 1948, 70, 4267.

5. Davis, B. D., Isolation of biochemically deficient mutants of bacteria by penicillin, J. Am. Chem. Soc., 1948, 70, 4267.

6. Adams, M. H., Methods of study of bacterial viruses, Methods Med. Research, 1950, $2,4$.

7. Libby, R. L., A simplified photronreflectometric technique for the titration of the antibody potency of antipneumococcal horse and rabbit serum, J. Immunol., 1938, 35, 289.

8. Novick, A., and Szilard, L., Experiments on spontaneous and chemically induced mutations of bacteria growing in the chemostat, Cold Spring Harbor Symp. Quant. Biol., 1951, 16, 337. 